\title{
Inventorization of Abandoned Mines and quarry Pits in Taraba State, Nigeria
}

\author{
Ahmed, Y.M. and Oruonye, E.D. \\ Department of Geography, Taraba State University, P.M.B. 1167, Jalingo, Taraba State \\ Nigeria.yushau20032003@gmail.com eoruonye@gmail.com \\ Tel: $07039271480 \quad 08033496833$.
}

\begin{abstract}
Although there have been so many studies on mining activities and their environmental impacts over the years, it is only recently that the issues of mine closure and rehabilitation have been included in mining discourse as contained in the Minerals and Mining Act 2007. Abandoned mine pits and their associated mine features constitute significant risk and environmental hazards to local communities and the natural ecosystem. This study undertook inventorization of abandoned mine sites in the state and classify the extent to which they negatively impact on the environment. This will facilitate screening of the abandoned mine sites in the state for reclamation and rehabilitation. Field identification of sites and assessment of mine features was carried out. Field assessment include measurement of mine pits dimension, quantity, volume, surface area, distance using GPS and description of the types of materials or products removed from the site. Physical hazard assessment approach was adopted. A hazard ranking system, or prioritization index (PI), was used to prioritize the mine site for reclamation and rehabilitation. The study listed 189 abandoned mine and quarry sites and visited 105 sites for detailed study. The study identified 8 abandoned mine sites that falls within the high risk hazard that were ranked for prioritization and reclamation. Most of the mining and quarry sites were abandoned as a result of communal conflicts, lack of modern equipment, inability to acquire licence and too much water in mine pond. The study recommends the need to enforce mining regulations and initiate the process of reclamation of the abandoned mine sites to reduce the dangers posed to host communities.
\end{abstract}

Keywords- Abandoned mine, Inventorization, Prioritization, Quarry pits, Reclamation and Taraba State.

\section{INTRODUCTION}

Mining is the process of extracting minerals from the earth surface in an environmentally friendly manner (Davou, 2013). Mining can also be regarded as the extraction of minerals occurring naturally such as coal, ores, crude petroleum and natural gas. Mining industries have been viewed as key drivers of economic growth and the development process (Bradshaw, 2005), and as lead sectors that drive economic expansion which can lead to higher levels of social and economic wellbeing (Bridge, 2008). Artisanal and small scale mining is one important livelihood activity that can help reduce poverty and achieve rural economic renewal through the development of nonfarm income generating opportunities. Previous studies have shown that solid mineral exploitation constitute more than $1 \%$ of Nigeria's GDP as most of the mining activities are still mainly carried out by the informal sector with over $95 \%$ of mining activities carried out by artisanal and small scale miners, out of which 95\% are illegal (Uzoka, 2001). The Federal government generate large revenue from mining activity from mine licence fees, mining permits, rents and royalties from mining companies. This money is deposited in a special account and later shared among the different states. Each state presents documents of mining activities taking place within its territory which is used as a basis in sharing the revenue among the component states in the country. However, mining operations oftentimes leave the affected environment severely degraded, physically and socially. Degradation commonly occurs at all stages of mining activities from exploration to mine closure, resulting from both large and small scale artisanal mining operations (Walde, 1992).

Taraba state is well endowed with abundant mineral resources. Many of these mineral resources have been explored and worked on in the past decades. Mining in Taraba state is dominated by artisanal and small scale miners (informal mining activities undertaken by individuals or groups who rely heavily on manual labour, using simple implements and methods). The small scale and artisanal miners' and the large scale industrial miners indiscriminately carryout extensive mining activities without any consideration to the environment and other users. These mining operations are mostly surface mining carried out with little or no advanced technology to manage the environment degraded by the mining operations (Oladipo, 2006). Increasing environmental damage is made worst by the fact that most of the miners undertake their operations illegally and have no official permission and their areas of operations are not known to government officials (Ahmed, 2013). This makes it difficult for the 
government to monitor their operations and also to enforce environmental regulations on them.

Mining of mineral resources is under the exclusive list of the Federal Government of Nigeria. This means that all mineral resources in the country is owned by the Federal Government of Nigeria and no State or Local council has right to explore, prospect or exploit mineral resources found in their territory without licence from the Federal Government. The 2007 mining law requires that anyone going into mining operation must apply and obtain mining licence or rights permitting them to do so. This has resulted to increasing numbers of illegal miners. Most of the illegal miners are uneducated and doesn't understand the rudiments of applying for mining licence which is usually from the Federal Ministry of Mines and Steel development, located in Abuja, the Federal Capital Territory.

Although there have been so many studies on mining activities and their environmental impacts over the years, it is only recently that the issues of mine closure and rehabilitation have been included in mining discourse as contained in the Minerals and Mining Act 2007. Most of the mines or affected mining pits were abandoned or left in an inadequate reclamation status. These abandoned mine pits and their associated mine features constitute significant risk and environmental hazards to local communities and the natural ecosystem. The activities of this artisanal and small scale miners litter the state with abandoned mine pits, 'lottos', trenches, ponds and mining dumps that pose serious danger to grazing livestock and human beings (Owolabi, 2013). It has been reported that the activities of the artisanal and small scale miners result in conflicts between livestock rearers, farmers and foresters on one hand and miners on the other hand (Ahmed, 2013).

Despite the widespread distribution of these unrehabilitated abandoned mines and their impact on communities in the state, there is limited knowledge about their existence, location and characteristics. Since the creation of the state in 1991, no effort has been made to inventorize these mine lands in the state. Inventorization will allow for remedial measures to be undertaken to rehabilitate and reclaim the sites in the state (based on zones).

Today, the Federal Government of Nigeria is faced with the challenges of reclaiming the abandoned mine lands and reducing their hazards at a time when the country is facing serious financial constrain, budget cut, land issues (crisis/conflict) and lack of comprehensive inventory of this abandoned mine pits. The first step in reclaiming these abandoned mines is inventorization. Inventorization is the process of identification of the abandoned mine sites, its location (longitude and latitude), type of mine sites, length, width, height and depth of mine pits or mine waste dumps among others. It is a process of generating information on the features of the abandoned mines. It is very important so that the extents of the problems are understood and commensurate effort put into the reclamation process. Unfortunately, despite the Federal government award of contract for a nationwide inventorization of these abandoned mine pits in 2006 (Ashawa, 2007), the government does not have adequate records of land degraded during these past operations in parts of the country where this artisanal and small scale mining took place (Ahmed, 2013). The report identified 1,200 abandoned mining sites across the country in its 2008 report (Premium Times, 2014). The report did not capture many of the abandoned mine sites in the state, only 18 abandoned mine sites was reported. This inadequate information makes future planning and policies of reclaiming, restoring and managing the abandoned mine sites difficult. After the nationwide inventorization of 2006, new mine sites have been worked and abandoned, hence the need for this inventorization.

This study is significant because it attempts to inventorize abandoned mine sites in the state and classify the extent to which they negatively impact on the environment. This will facilitate screening of the abandoned mine sites in the state for reclamation and rehabilitation. This study also provides a baseline data which include careful documentation of the locations, extent of impacts, nature of minerals mined, the type of mining methods used, mine pits dimension, overburdens and scraps of equipment/machines of the mine sites in the state. The main reasons for inventorization of abandoned mine sites usually include;

i. An indication of the quantity of minerals mined in the state and its resultant contribution to the Nigerian Economy since all revenue generated are sent to the Federal Government account.

ii. A basis of sharing of revenue generated from the State by the Federal government according to the mineral revenue sharing formula by the Revenue Mobilization, Allocation and Fiscal Commission (RMAFC).

iii. A licence data for the state to apply for its own revenue share from the Federal Government.

iv. Assist the State and Federal Government in creating database for degraded mine sites.

v. Prioritization of the mine sites for reclamation when the need arises.

vi. Reduce in future, the fund to be spent in carrying out the inventorization exercise.

The baseline data generated from the study will help in the formulation of mining and environmental policies for the state to reclaim, restore and rehabilitate environments degraded by past mining activities. The study will enrich existing literature on the activities of artisanal and small scale miners, and also the large scale miners in the state. 
Description of Study Area

Taraba State is found in the north eastern part of Nigeria. It is located between latitude $6^{\circ} 25^{\prime} \mathrm{N}$ and $9^{\circ} 30^{\prime} \mathrm{N}$ and between longitudes $9^{\circ} 30^{\prime} \mathrm{E}$ and $11^{\circ} 45^{\prime} \mathrm{E}$. It is bordered on the west by Nassarawa and Plateau States, to the north by Bauchi and Gombe States and by Adamawa State to the northeast (Figure 1). The population of Taraba State, according to the 2006 National Population Census, was $2,300,736 \quad(1,199,849 \quad(52.2 \%)$ males and $1,100,887$
(47.8\%) females). There were 98,962 more males than females. The state has a population growth rate of about $3.1 \%$ per annum. Taraba State is the most ethnically diverse state in the Federation with over 80 different ethnic groups. Ethnic groups found in the state include Mumuye, Ichen, Wurkun, Mambila, Kuteb, Chamba, Jukun, Tiv, Yandang, Fulani, Jenjo, Kunini, Ndoro, Kambu, Kaka, Bandawa, Munga, Zo and Banbuka.

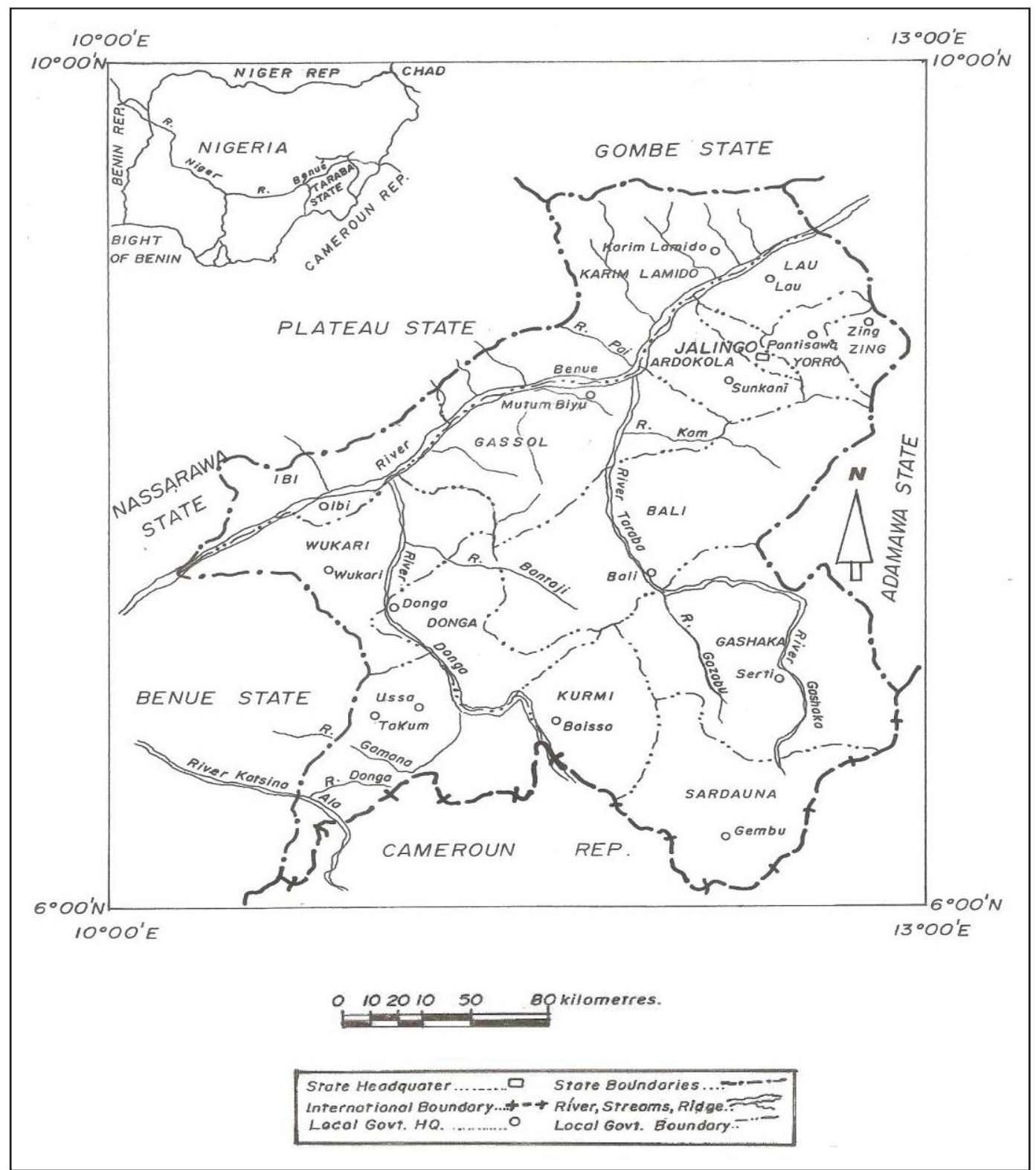

Fig.1: Map of the Study Area

The State has climatic types that ranges from northem equatorial type in the southern part of the state (Kurmi, Ussa and Takum LGAs) to the Tropical hinterland type (Donga, Gashaka and Wukari LGAs) to Tropical continental type of climate in northern part of the State (Yorro, Zing, Lau, Jalingo and Ardo Kola LGAs). The Mambilla area is a montane climate type. This climatic types have greatly influenced the vegetation types in the state. The vegetation types ranges from the tropical rainforest around Kurmi, Uss a and Takum LGAs to Guinea savannah in the central part of the state and Sudan savannah type in the northern part. Montane vegetation is found on the Mambilla plateau and Shebshi mountain and flood plain complex is found along the major rivers in the state.

Geologically, Taraba State is underlain by Basement Complex and sedimentary rocks, each occupying a very distinctive part of the state. The Basement Complex rocks 
occupy the greatest part of the state (above $80 \%$ ), while the sedimentary rocks are found along the valleys of River Benue and its major tributaries such as Rivers Donga and Taraba. The geological formation of the state provided the basis of the rich solid mineral resource potentials that the state is known for.

The state is an agrarian state with about 80 percent of the populations directly engaged in agriculture while 20 percent are engaged in other economic activities including white collar job (TSEEDS, 2004). Common crops cultivated include cereals, legumes and tubers such as maize, rice, groundnut, beans, cass ava and yam. Tree crops in the area include palm oil, banana/plantain and orange. Cash crops produced in the state include coffee, tea and groundnut. The State's agricultural sector is dominated by small scale rural farmers. The state has over 52 discovered solid mineral resources with the highest hydroelectricity power potential in the whole country. It is a tourist haven with the largest National park in West Africa (Gashaka Gumti National Park).

\section{METHODS OF DATA COLLECTION}

The method of carrying out inventorization of abandoned mines varies across different countries depending on the scale and peculiarity of the local mining environment. The inventorization of abandoned mines in the state was carried out in three stages:

i. Desktop review and consultation of some miners to identify abandoned mine sites in the state which were legally or illegally mined and the damaged environment.

ii. Field assessment of identified sites.

iii. Prioritization of sites for reclamation.

\section{Stage I - Field Identification of Sites}

The first task was identification and collation of list of abandoned mine sites. Primary and secondary data collection methods were employed in doing this. Secondary data involved desk review of existing literature and archival records from relevant government agencies and organizations. The researchers liaised with staff of the Federal Ministry of Mines and Steel Development in Jalingo and the State Bureau of Solid Mineral Resources in obtaining some list of abandoned mine sites in the state. Six (6) officials of government agencies were interviewed. Interviews was also carried out with seven (7) traditional leaders, 15 host community members and nine (9) renowned licensed small scale miners in the state to obtain additional list of abandoned mine sites. Interviews were preferred to the use of questionnaire due to limited number of small scale miners and other key informants. All the people interviewed were men who have knowledge of the mining activity in the area. The renowned small scale and artisanal miners and traditional village Heads assisted in directing the researchers to the abandoned mine sites. Most of the abandoned mine sites are found close to some active www.ijeab.com mining sites which were illegal and as such the miners react aggressively to any visitor to the site perceived to be government officials. There were cases of illegal miners attacking government officials on field survey to mining sites. Thus, the company of these old miners and village Heads assisted greatly in easing tension and providing direction to the location of abandoned mine sites in their communities. The study focused on the physical environment and description of features of the abandoned mines. Abandoned mine site assessment parameters were developed.

\section{Stage II - Field Assessment}

The large number of abandoned mine sites identified in step one above and the lack of accessibility to some of the sites, limited the field assessment to only sites that are accessible by means of transportation and trekking distance. The field assessment involved accessing the mine site, observation of mine features; measurement of mine pits dimension and photography. The recording of observations focused on quantifiable details such as quantity, volume, surface area and distance and descriptions of the types of materials or products removed from the site. Measuring tape was used to measure the extent of degraded areas as a result of past mining operations. For very large areas where measuring tape was not adequate, the Garmin Global Positioning System (GPS) was used. The volume of the areas of physical damage was calculated in the field. The choice of this method was because of its precision and ease of application. Only the GPS, measuring tape, ropes and pegs was required. This helped in the description of the features of the various abandoned mine sites in the state. The coordinate data of the locations of abandoned mine and quarry sites visited during the fieldwork was georeferenced to Minna datum, UTM zone $32 \mathrm{~N}$. This was overlay to satellite data obtained from the United State Geological Survey (USGS) online open resources. The locations of abandoned mine and quarry sites were identified by attribute and spatial query. This enables us to map out the locations of the abandoned mine and quarry sites.

Stage III - Risk Assessment and Prioritization of Mine Sites

The hazard risk assessment approach adopted in this study is the physical hazard assessment approach. The approach was adopted to provide an objective basis of prioritization of abandoned mines and quarries which is a major prerequisite for resource allocation in mine reclamation exercise. The 2 broad group of risk usually as sociated with mining sites are human safety risk and environmental risks. Reference is usually given to human safety risk, while the environmental risk requires time, more resource and time to achieve good results. Information on the physical hazards collected during field inventory work consist of direct measurement and observations of physical conditions that reveals environmental and public safety

Page | 1807 
conditions of the abandoned mine and quarry sites visited. The public safety data include identifying dilapidated mine structures and equipment, mine openings, pits/lottos, high walls and sink holes.

The study adapted the risk assessment approach that is modified from USEPA's source-pathway-target. This is a numerically derived system of assigning numeric values (scores) to abandoned mine site base on quantifiable measures of hazardous physical features and associated exposure potential of the mine sites (Ashawa, 2007). This method provides for relatively rapid, uniform and objective prioritization of abandoned sites. The hazard risk index used in this study are

i. Accessibility (such as distance, degree, and type of road development in the area)

ii. Number of mine openings in an area

iii. Closeness of mine site to major road

iv. Location of mine site close to high residential areas and

v. Pollution of pond water etc.

The prioritization for reclamation was based on public safety and environmental concerns. Here the study considers dangers posed by the mine site in arriving at its prioritization for reclamation. These dangers include its location close to high residential areas, farmlands/grazing lands. The mines were scored numerically based on their site features, proximity to high residential areas and accessibility, and then ranked by their scores. Higher scoring areas are higher risk and higher priority for reclamation. The approach adopted some simple ceteris paribus assumptions that are grounded in common sense (Rohrer and Smith, 2008). They include; all things being equal, an area with multiple mine openings is a higher risk than an area with only one or very few opening, all things being equal, areas close to high population is at higher risk than one located in area of low population and all things being equal, a mine in an area close to major roads is at higher risk than a mine in an area without road. All hazards observed were rated by the researchers on the site. The hazards rating was reviewed with the help of video clips and photographs. The information on hazard rankings was used to prioritize the mine site for reclamation and rehabilitation. The data generated from the field were collated and analysed using descriptive statistics.

\section{RESULTS/DISCUSSIONS}

The study listed 189 abandoned mine and quarry sites with 28 different minerals (Table 1). However, because of security challenges and inaccessibility, only 105 mine/quarry sites (Fig.2) as sociated with 13 minerals were visited during field inventory works (Table 2). The summary of the minerals associated with the listed mine sites is presented in Table 1 .
Table.1: Types of Minerals Associated with listed Sites in the State

\begin{tabular}{|c|c|c|}
\hline $\mathrm{S} / \mathrm{N}$ & Types of Minerals & Frequency \\
\hline 1 & Aquamarine & 3 \\
\hline 2 & Alluvial Gold & 7 \\
\hline 3 & Amethyst & 7 \\
\hline 4 & Barite & 22 \\
\hline 5 & Bauxite / aluminium & 2 \\
\hline 6 & Beryl & 9 \\
\hline 7 & Calcite & 1 \\
\hline 8 & Columbite & 1 \\
\hline 9 & Copper & 3 \\
\hline 10 & Dolomite & 1 \\
\hline 11 & Feldspar & 1 \\
\hline 12 & Galena & 17 \\
\hline 13 & Gemstone & 9 \\
\hline 14 & Granite & 2 \\
\hline 15 & Graphite & 2 \\
\hline 16 & Quartz & 1 \\
\hline 17 & Indus trial Nickel & 1 \\
\hline 18 & Laterite & 45 \\
\hline 19 & Lead & 11 \\
\hline 20 & Limestone & 1 \\
\hline 21 & Molybdenum & 3 \\
\hline 22 & Sapphire & 12 \\
\hline 23 & Shillite & 1 \\
\hline 24 & Tantalite & 5 \\
\hline 25 & Tin & 4 \\
\hline 26 & Topaz & 2 \\
\hline 27 & Tourmaline & 7 \\
\hline \multirow[t]{2}{*}{28} & Uranium & 6 \\
\hline & Total & 186 \\
\hline
\end{tabular}

Source: Fieldwork, 2017

Table.2: Types of Mineral Sites Visited

\begin{tabular}{|l|l|l|}
\hline S/N & Types of Minerals & Frequency \\
\hline 1 & Alluvial Gold & 1 \\
\hline 2 & Amethyst & 1 \\
\hline 3 & Barite & 16 \\
\hline 4 & Copper & 2 \\
\hline 5 & Galena & 16 \\
\hline 6 & Gemstone & 7 \\
\hline 7 & Granite & 2 \\
\hline 8 & Laterite & 45 \\
\hline 9 & Lead & 4 \\
\hline 10 & Molybdenum & 2 \\
\hline 11 & Sapphire & 4 \\
\hline 12 & Tourmaline & 2 \\
\hline 13 & Uranium & 3 \\
\hline & Total & 105 \\
\hline
\end{tabular}

Source: Fieldwork, 2017 


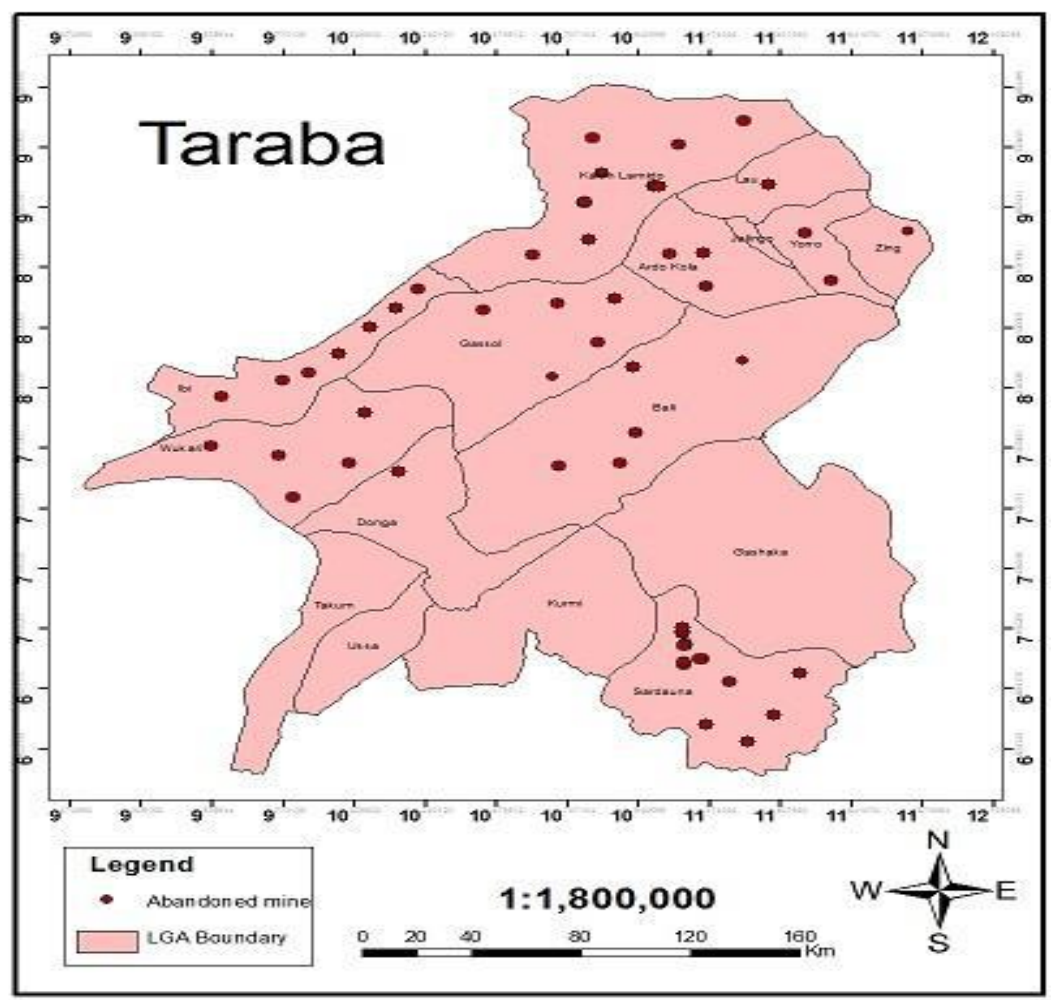

Fig.2: Abandoned Mine and Quarry Sites in Taraba State

An inventory of quarrying and mining titles in Nigeria in 2012 by the Federal Ministry of Mines and Steel Development reported 182 titles issued out from Taraba state (Table 3).

Table.3: Mining Leases in Taraba State

\begin{tabular}{|l|l|l|l|}
\hline S/No. & Type of Title & Number & Type of Mineral \\
\hline 1. & Mining lease & 42 & Barites \\
\hline 2. & Mining lease & 7 & Gems tone \\
\hline 3. & Exclusive Prospecting licence & 104 & Barytes \\
\hline 4. & Exclusive Prospecting licence & 27 & Gems tone \\
\hline 5. & Exclusive Prospecting licence & 2 & Limestone \\
\hline 6 & Total & 182 & \\
\hline
\end{tabular}

Source: MSMD (2012)

Of the 182 mining lease and titles is sued out from Taraba State, 172 were from 4 LGAs, Ibi (40), Karim Lamido (44), Sardauna (37) and Wukari (51). In 2015, there were 77 mining titles reported in the inventory of quarrying and mining titles issued by the Federal Ministry of Mines and Steel Development from Taraba state as shown in Table 4.

Table.4: Mining Title in Taraba State (2015)

\begin{tabular}{|l|l|l|}
\hline S/No. & Type of Title & Number \\
\hline 1. & Mine lease & 6 \\
\hline 2. & Quarry Lease & 14 \\
\hline 3. & Small Scale Mine Lease & 18 \\
\hline 4. & Exploration Lease & 39 \\
\hline 5. & Total & 77 \\
\hline
\end{tabular}

Source: MSMD (2015)

Findings from the study revealed that there are many small scale and artisanal mining that are not illegal contrary to previous speculations by some scholars. There is now an appreciable awareness among the small scale and artis anal miners and the mining communities that you cannot exploit a mineral resource without an approved mining licence/lease from Federal Ministry of Mines and Steel Development. Most of the small scale and artisanal miners on discovering a mineral deposit will look for a mining firm or individual who has a mining licence to lease the 
area of deposit (mine) to him. Most communities are becoming more conscious of protecting the mineral resources in their communities. The approved mining licence is the only document that allows the prospective miners the right to exploit the mineral deposit and the people's cooperation in this regard. One of the conditions of obtaining a mining lease or licence is payment of compensation of property to local communities. Findings of the study shows that large quantities of mineral ore deposits have been mined out in the state and large

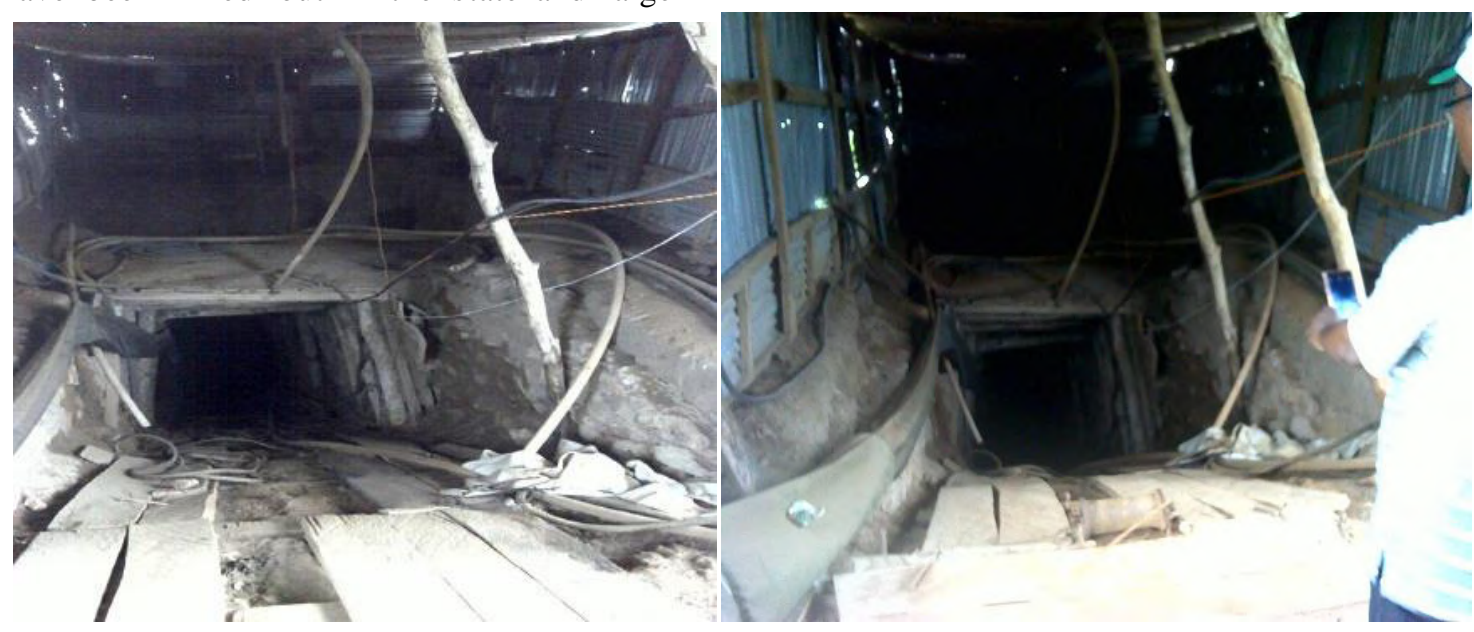

Plate.1: Underground mining Tunnel at Jukun Village in Karim Lamido LGA numbers of abandoned mine sites exist as a result of past mineral exploration /exploitation in the form of test pits, lotos and open ponds.

\section{Mining Methods Employed in Abandoned mines}

Findings of the study shows that most of the abandoned mine sites in the state are surface mining with open pits/cast. There are only 2 underground mining tunnels at Jukun and Ameche communities in Karim Lamido LGA (Plate 1).
The open pits mining method is a common choice because of the mining implement and characteristics of the ore deposit (e.g. location of mineral veins close to the surface) which makes the removal of the overburden (i.e. host rock overlying the mineral laden ore) cost effective. It is the most economical method of mining in the area because it involves use of simple crude implements. The method involves excavation of an area of overburden and removal of the ore exposed in the resulting pit (USEPA, 2000). The history of poor open cast mining practices in the state and lack of post-mining closure or reclamation measures have left large expanse of wasteland in the state. The total size of the mine openings in the sites visited is $57,196,942 \mathrm{~m}^{3}$. The largest of this mine opening are found in Wukari, Gassol, Donga and Ibi LGAs. Most of the abandoned mine openings were mainly laterite excavated pits used for road construction in the area. Ibi LGA has large abandoned open barite mine openings with large water collection used for domestic and animal consumption. The distribution of these mine openings is presented in Figure 2.

The largest quantities of wastes generated by mining operations are mine water and overburden which is generated at surface mines and with time washed away by erosion. Overburden is the surface material (i.e. topsoil and rock) removed during surface mining operations to expose the ore deposit beneath. The total volumes of overburden materials generated as a result of mining in the area is about $745,984 \mathrm{~m}^{3}$. The distribution of the overburden materials is presented in Figure 3. 


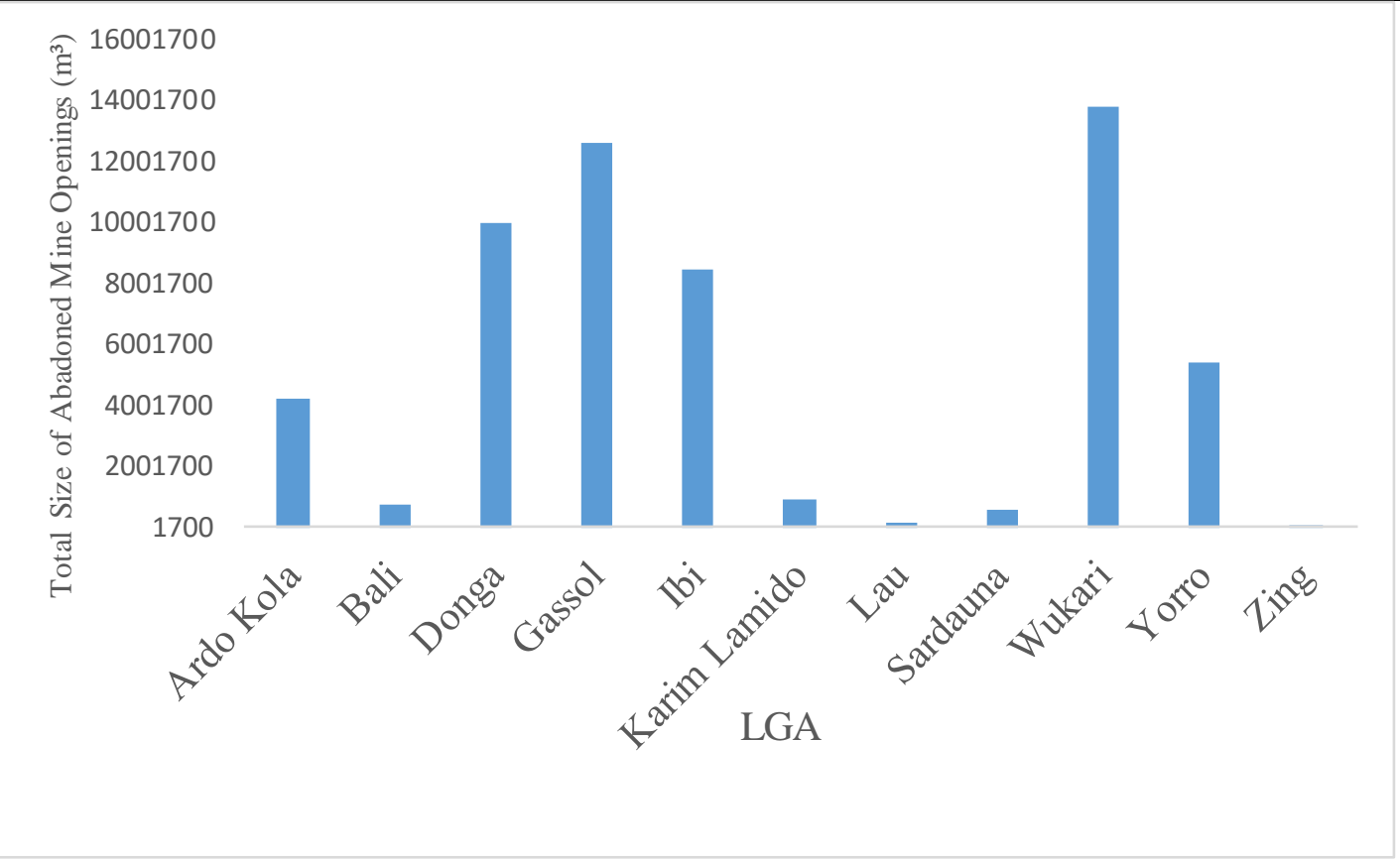

Fig.2: Magnitude of Abandoned Mined Openings in the State

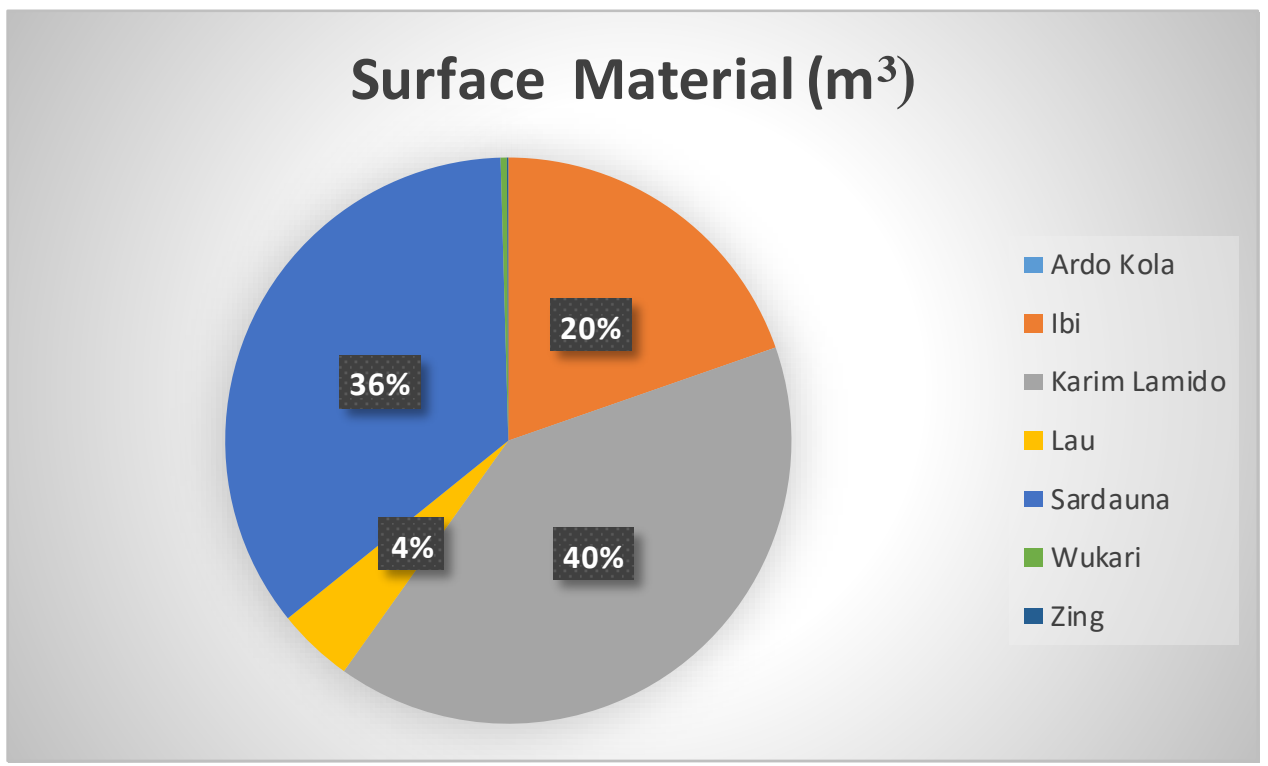

Fig.3: Volume of overburden materials at the abandoned mine site.

The availability of these wastes dumps at the abandoned mine site is very important in the description of the mine site features as it indicates the availability of materials for reclamation of the site and the less cost of the mine reclamation. If there are no overburdens at the site, the cost of reclamation would be expensive as materials needed would have to be obtained from other available locations and transported to the sites.

\section{Causes of mine abandonment}

Abandoned mines are those mines for which the owner cannot be found or for which the owner is financially unable to carry out reclamation after mining activities. The cause of mine abandonment varies across the country.
However, some of the causes of mine abandonment in the study area include;

i. Lack of Regulations/Policies - many mining sites were abandoned in the past because there were no laws stipulating that those sites should either be reclaimed or rehabilitated whenever they were no longer active. The first mining law of 1946 has no detailed provisions about mine reclamation. This was reviewed in the Mining Act 2007 which prescribed certain standards for mining site reclamation. The new mining Act stipulate obligation on the mineral title holders to reclaim the site before they vacated a mining site. However, the mining law is not fully circulated 
for the communities to know their right. This is further made worst by the lack of capacity on the part of government to enforce the new mining regulations. This contributes to the increase in the number of abandoned mine sites.

ii. Economic - fluctuation in the prices of mineral resources which leads to sudden drop in the prices of mineral products could lead to abandonment of mining activities.

iii. Small Scale mining - the uncoordinated and uncontrolled occupation of mine sites by small scale and artisanal or illegal miners in Nigeria (who usually practice seasonal mining) has often led to a site been abandoned (Ashawa, 2007). This often leaves the government with the responsibility of reclaiming such abandoned mine site. Some mine and quarry sites are abandoned because some miners lacked the licence to mine such site. Thus, abandoned for fear of arrest by government and security officials of the state.

iv. Technical - the common method of mining in the area which is open cast method have led to the destruction of many mining sites and subsequent abandonment of such sites because of excessive soil tillage. Miners lacked modern equipment to mine the deposits. Many mine and quarry sites are also abandoned because of excess water level in the mine pond which often over-powered the miners and their equipment especially during the rainy season.

v. Conflicts - communal conflicts and clashes between crop farmers and cattle herders, different ethnic and religious groups among others has led to the abandonment of mining sites as observed in Ibi and Sardauna LGAs.

Many other mines were abandoned as a result of insufficient minerals in the area, while others were abandoned when it was discovered that the mining is becoming unprofitable. Some abandoned mine sites have large mineral deposits but the miners lacked the required equipment to mine the deposits. Thus, some abandoned mine sites are rich mineral deposits sites that could be exploited in the future.

\section{Effects of abandoned mines}

The issue of abandoned mines is important because it represents many former mining sites abandoned and that continued to pose real or potential threat to human/animals safety, health and/or environmental damage. In many areas this is considered a negative legacy of the mining industry and is important because it both demonstrates a lack of care and planning in past practice and adherence to regulations that were inadequate because of the lack of detailed understanding (MMSD, 2002). Abandoned mines are associated with many effects on the physicalenvironments and human beings which can be grouped into environmental, socio-economic and health concerns.

i. Environmental - these includes: unused open pits, deforestation, degraded landscape, mine shafts, impoverished soils, degradation and contamination of groundwater; pollution of surface water by sediments or overburdens, changes in groundwater regime, air pollution from dust or toxic gases and risk of falls into open pits, contamination of soils and aquatic sediments among others.

ii. Socio-economic - the human related problems include conflicts, loss of arable lands, loss of income and employment opportunities as a result of decline in business activities within local communities, population migration and pressures on infras tructural facilities.

iii. Health - the existence of abandoned mine and quarry sites provide breeding grounds for disease vectors and a hiding place for dangerous reptiles. Many abandoned mine pits contain water (pond) which is used by the community for human and animal consumption. Water from abandoned mines may contain significant concentrations of heavy metals and total dissolved solids and may have elevated temperatures and altered $\mathrm{pH}$, depending on the nature of the ore body and local geochemical conditions. These waters may become acidic over time when exposed to oxygen and, if present, pyrites or other sulfide minerals. The acidic water may also solubilize with the metals contained in the mine and mined materials, creating high concentrations of metals in solution. These acidic metal-laden waters may contaminate down-gradient ground-water and surface water resources (USEPA, 2000). Some of the ponds at the sites were now being used for irrigation farming, fishing and water supply for domestic and industrial purposes. Although some of the abandoned mine pond water is used for domestic consumption, the water is not good for drinking as it is untreated. This constitutes a health hazards/challenge even though it solves a lot of local water needs problem.

iv. The existence of abandoned mine sites has serious effect on crop yield. This is especially for crops grown in mine sites where the minerals are poisonous to humans. This can result to food poisoning from contaminated crops and low crop yield.

The findings of the study show that there are some sites that are not posing problems contrary to earlier assumptions. Many other sites are risk sites to humans and 
animal lives, death traps especially in the sapphire mining areas where mining pits with lotos killed humans and animals. There are few sites with large quantity of equipment, whereas there are numerous sites with only a few equipment items left behind on the site.

Effort of government can be oriented towards those few sites containing such dangerous products and evaluate the opportunity to clean up and reclaim the other problematic sites according to clearly identified criteria such as potential danger to the environment and human health and the proximity between the sites and the communities.

Abandoned mine workings may be an environmental hazard because of the pos sibility of subsidence or collapse. They can also channel contaminated ground water flow, particularly if they are located in sulphide mineral bearing rock and contain water.

\section{Prioritization of Abandoned Mine}

Prioritization of abandoned mine for reclamation is the main objective for carrying out inventorization of abandoned mine. The abandoned mine sites identified were ranked and listed by priority based on health and environmental risk and threats associated with the sites to humans and livestocks. The rating of sites was based on the potential degree of their human and environmental hazard. The findings of the study show that about 8 mine and quarry sites falls within the high hazard risk as shown in Table 5.

Table.5: Hazard ratings of abandoned mines and quarry sites

\begin{tabular}{|c|c|c|c|c|c|}
\hline S/No. & Mine Site & Location & Mine Feature & $\begin{array}{l}\text { Average Risk } \\
\text { Score }\end{array}$ & $\begin{array}{l}\text { Ranking for } \\
\text { prioritization }\end{array}$ \\
\hline 1. & $\begin{array}{l}\text { Jauro Yinu - } \\
\text { Ardo Kola LGA }\end{array}$ & $\begin{array}{l}08^{\circ} 53^{\prime} 42^{\prime \prime} \mathrm{N} \\
11^{\circ} 16^{\prime} 56^{\prime \prime} \mathrm{E}\end{array}$ & $\begin{array}{l}\text { Located within residential area, } \\
\text { children swim in ponds and use } \\
\text { for farming }\end{array}$ & 72 & 3 \\
\hline 2. & $\begin{array}{l}\text { Iware - Ardo } \\
\text { Kola LGA }\end{array}$ & $\begin{array}{l}08^{\circ} 49^{\prime} 23^{\prime \prime} \mathrm{N} \\
11^{\circ} 05^{\prime} 52^{\prime \prime} \mathrm{E}\end{array}$ & $\begin{array}{l}\text { Located within residential area. } \\
\text { The pond is deep and constitute } \\
\text { high hazard risk in the area }\end{array}$ & 80 & 2 \\
\hline 3. & $\begin{array}{l}\text { Dan Anacha- } \\
\text { Gassol LGA }\end{array}$ & $\begin{array}{l}08^{\circ} 13^{\prime} 57.1^{\prime}{ }^{\prime} \mathrm{N} \\
10^{\circ} 20^{\prime} 01.6^{\prime}{ }^{\prime} \mathrm{E}\end{array}$ & $\begin{array}{l}\text { Found in residential area and high } \\
\text { hazard risk }\end{array}$ & 68 & 5 \\
\hline 4. & $\begin{array}{l}\text { Gindin Waya- } \\
\text { Ibi LGA }\end{array}$ & $\begin{array}{l}08^{\circ} 05^{\prime} 51^{\prime \prime} \mathrm{N} \\
09^{\circ} 46^{\prime} 59.8^{\prime \prime} \mathrm{E}\end{array}$ & $\begin{array}{l}\text { Mine was abandoned due to too } \\
\text { much water and difficulty of } \\
\text { draining it out. Serious hazard } \\
\text { because of depth }\end{array}$ & 58 & 8 \\
\hline 5 & $\begin{array}{l}\text { Jukun - Karim } \\
\text { Lamido LGA }\end{array}$ & $\begin{array}{l}09^{\circ} 05^{\prime} 09.1^{\prime \prime} \mathrm{N} \\
10^{\circ} 45^{\prime} 46.4^{\prime \prime} \mathrm{E}\end{array}$ & $\begin{array}{l}\text { Large mine pond surrounded by } \\
\text { farmlands/grazing lands. A } \\
\text { woman died in the pond while } \\
\text { trying to rescue her child. }\end{array}$ & 84 & 1 \\
\hline 6 & $\begin{array}{l}\text { Maisamari } \\
\text { Sardauna LGA }\end{array}$ & $\begin{array}{l}07^{\circ} 08^{\prime} 36^{\prime \prime} \mathrm{N} \\
11^{\circ} 05^{\prime} 05^{\prime \prime} \mathrm{E}\end{array}$ & $\begin{array}{l}\text { Mine pits with horizontal lotos } \\
\text { dangerous for humans and } \\
\text { grazing animals }\end{array}$ & 66 & 7 \\
\hline 7 & $\begin{array}{l}\text { Akwana - } \\
\text { Wukari LGA }\end{array}$ & $\begin{array}{l}07^{\circ} 47^{\prime} 01{ }^{\prime \prime} \mathrm{N} \\
09^{\circ} 09^{\prime} 30^{\prime \prime} \mathrm{E}\end{array}$ & $\begin{array}{l}\text { So many open mine pits within } \\
\text { farmlands/grazing lands }\end{array}$ & 68 & 5 \\
\hline 8 & $\begin{array}{l}\text { Jankwani - } \\
\text { Monkin, Zing } \\
\text { LGA }\end{array}$ & $\begin{array}{l}08^{\circ} 46^{\prime} 42^{\prime \prime} \mathrm{N} \\
11^{\circ} 43^{\prime} 16^{\prime}{ }^{\prime} \mathrm{E}\end{array}$ & $\begin{array}{l}\text { Very deep open pit around } \\
\text { residential areas that can serve as } \\
\text { death trap for animals and } \\
\text { humans }\end{array}$ & 72 & 3 \\
\hline
\end{tabular}

Source: Fieldwork, 2017.

\section{Limitations of the Study}

Studies of this nature are fieldwork based and required physically visiting all the listed abandoned mining site and observing the features of such mine/quarry sites. Most of the abandoned mine sites were located in remote and inaccessible locations by any means of transportation. This will require long trekking for several kilometres and hours through bush path which will amount to more time and cost. This is also made worst by insufficient information on the location of most abandoned mine sites especially those carried out illegally.

Secondly, the recent economic hardship in the country has made it difficult for most people to avail researchers with useful information without demanding for token payment. Thus, the researchers have to pay local guides to the mining site and the Village Head for assistance. Any researcher 
attempting to go to an abandoned or active mine site without the knowledge, permission or company of the Village Head, local miner or Villager stand the risk of been attacked by the local community. This development has increased the cost of this research and made it difficult for the researcher to reach all the listed abandoned mining sites in the state.

The study was carried out during rainy season between June to September 2018, because this was the time that funds were made available to the researchers. The researchers started work immediately. This increased the challenges encountered during the study. The depth of most of the open mine pits were estimated instead of actual measurement because they were filled with waters at the time of the study. The rainy season also led to suspension of mining activities in most active mine sites because of the difficulties of dewatering the pits as a result of high rainfall.

The recent crisis on Mambilla plateau made it difficult for the researchers to access some important sapphire mine sites. Some mine pits (especially those with lottos) were used as dumps for human/animals during the crisis, which may lead to serious health hazard considering the topography of the area as a result of underground water movement in the area. This also made it difficult for the research team to visit some abandoned mine sites at hot spot of the conflict. The local communities are becoming very conscious of movement of strangers into their communities because of the recent security challenges in the state and region particularly between the herdsmen and farmers. Thus, the researchers spent much time explaining their mission to local communities to get their consent to visit the mine sites.

\section{CONCLUSION}

This study has inventoried abandoned mines and quarry sites in Taraba state. The study has as sessed the hazard risk associated with the investigated abandoned mine and quarry sites and ranked them for prioritization. The study ranks 8 of the identified high risk hazard sites for prioritization and reclamation. The study has thus provided an insight into effects of abandoned mine and quarry sites and baseline data that could help in the reclamation of the abandoned mine and quarry sites in the state. The study reveals the problems posed by the lack of data on most of the abandoned sites to is sues of reclamation in the future in the state. Although there is new mining exploration and exploitation regulation in the country, this inventory suggests that a lot remains to be done to redress negligence from the past, and to harmonise future economic development with environmental concerns. The potential costs of reclamation, the lack of clearly assigned responsibility, the absence of criteria and standards of mine reclamation and other factors have continued to delayed action by governments and stakeholders.

\section{RECOMMENDATION}

Based on the findings of the study, the following recommendations were made;

1. There is need for the Federal Ministry of Mines and Steel to work hand in hand with the Taraba State Bureau for Solid Mineral resources. This will help in the enforcement of the new mining regulation and reduction in the level of land degradation related to illegal mining.

2. There is need for the state government to commission a research into inventory of the abandoned mine and quarry sites that will extend to areas that were not covered by the present study.

3. There is need for the government to clearly define the criteria and standards of mine reclamation and assign responsibility to stakeholders concerned.

4. It is important that the State government liaise with the Federal government in initiating the process of reclamation of the identified abandoned mine and quarry sites to reduce the dangers posed to communities in the area. This is important since mining is under the Federal exclusive legislative list and mining involves taking over lands in the states.

5. Establishment of mine reclamation unit in the State Bureau of Solid Mineral Resources. This unit will be charged with the responsibility of carrying out reclamation activities in the state when the need arises especially emergency reclamation exercises that is of manageable scope and specification.

6. Severe sanctions should be meted to individuals/groups and organizations that operate and abandoned a mine or quarry site without proper reclamation as stipulated in the new mining guidelines of 2007.

7. There is need for the government to come up with Environmental Protection and Rehabilitation Fund which will be funded through contributions from mineral title holders over a period of time. This fund can be used to carry out reclamation of the abandoned mines and quarry sites, given priority to high risk hazard sites.

\section{ACKNOWLEDGEMENT}

The authors are grateful to Tertiary Education Trust Fund (TETFund) Abuja, Nigeria for approving research grant for this study. We are also grateful to the Management of Taraba State University (TSU) Jalingo, for facilitating the grant. The authors expressed unreserved gratitude to the 
TSU Tet fund desk officer for his physical and moral support that saw to the success of the study. Special thanks to Ismaila Usman and Alhaji Ahmed Mustapha Babasoro, Chief Executive of Manji Enterprises Nigerian Limited, for assisting with the fieldwork inventory works.

\section{REFERENCES}

[1] Ahmed, Y.M. (2013). Characterization of Artisanal and Small Scale Mining in Parts of Taraba State Nigeria. An Unpublished Ph.D Thesis submitted to the Department of Geography, University of Jos.

[2] Ashawa (2007). Inventory of Abandoned Mines and Quarries: Action Plan for Remediation and Reclamation. Final Report of the Sustainable Management of Mineral Resources Project Submitted to the Federal Ministry of Solid Mineral Development (MSMD), Abuja, Nigeria.

[3] Bradshaw, M.J. (2005). Population, Resources, Development and the Environment. In: Daniels, P. et al, eds. An Introduction to Human Geography: Issues for the $21^{\text {st }}$ century. $2^{\text {nd }}$ ed. (section 2 ).

[4] Bridge, G. (2008). Economic Geography: Natural Resources. In: International encyclopaedia of Human Geography. Eds. Kitchin and Thrift. Elsevier.

[5] Davou, D.D. (2013). Introduction. In Short Course on Environmental Procedures, Nigerian Institute of Mining and Geoscience, September $2^{\text {nd }}$ to $6^{\text {th }}, 2013$, Jos Nigeria

[6] Ministry of Solid Mineral Development (2012). Inventory of Mining and Quarrying Titles in Nigeria, Mines Department, Abuja. November, 2012.

[7] Ministry of Solid Mineral Development (2015). Inventory of Mining and Quarrying Titles in Nigeria, Mines Department, Abuja.

[8] Premium Times Online Newspaper April 6, 2014. Nigeria identifies 1,200 abandoned mining sites. http://www.premiumtimesng.com/news/158188nigeria-identifies-1200abandoned-miningsites.html accessed on august 17, 2017

[9] Oladipo, S.O. (2006). Status of Nigerian Mineral Resource Industries (ASSM Perspectives). Being a presentation at the Nigerian Mining and Geosciences International Conference, Kaduna.

[10] Owolabi, A.O. (2013). Environmental Impact of Mining in Nigeria (A Case Study of ASM Operations). In Short Course on Environmental Procedures, Nigerian Institute of Mining and Geoscience, September $2^{\text {nd }}$ to $6^{\text {th }}, 2013$, Jos Nigeria 2006).

[11] Rohrer, J. C. and Smith, D. (2008). GIS as a Prioritization and Planning tool in abandoned mine reclamation. A Paper presented at "Incorporating
Geospatial Technologies into SMCRA Business Processes", March 25 - 27, 2008, Atlanta, GA.

[12] Taraba State Economic Empowerment Development Strategy (TSEEDS). A Comprehensive Poverty Reduction, Growth and Sustainable Development Strategy for Taraba State Nigeria. September, 2004.

[13] United State Environmental Protection Agency (USEPA, 2000). Abandoned Mine Site Characterization and Cleanup Handbook. Seattle, WA 98101.

[14] Uzoka O., Chairman, House Committee on Solid Minerals, National Assembly, Nigeria, Interview with Thisday Newspapers.http://www.this dayonline.com/archive/ 2001/08/26/200110826news 12.html> visited on March 17, 2002

[15] Walde, T. (1992). "Environmental Policies Towards Mining in Developing Countries". Journal of Energy and Natural Resources, 10(4): 327 - 357. 